\title{
IN-VIVO AND IN-VITRO STUDY OF THE RELATION BETWEEN CADMIUM AND BREAST CANCER
}

\author{
$\mathcal{B Y}$ \\ Mona A. El-Harouny, Adel M. El-Mansory, Amal A. El-Bakary, \\ Sameh Roshdy*, Hend M. Abo El-Atta and Farid A. Badria** \\ Departments of Forensic Medicine and Clinical Toxicology, Faculty of Medicine and **Pharmacognosy, \\ Faculty of Pharmacy, *Oncology Center, Mansoura University, Egypt.
}

\begin{abstract}
Cadmium is a potent carcinogenic environmental pollutant that has been lastly linked to breast cancer. This research was done to find out the role of cadmium in induction of breast cancer both in-vivo and in-vitro. In-vivo study was conducted on 100 female patients who were randomly chosen from those attending Oncology Center, Mansoura University. Cadmium concentration was measured in urinary and tissue samples from 75 patients with breast cancer (test group) and 25 patients with benign breast diseases (positive control group), using inductive coupled plasma (ICP) - spectrometer. In-vitro study included primary cultured normal mammary cells that were divided into test group (treated with $\mathrm{CdCl}_{2}$ at a concentration of $15 \mu \mathrm{M}$ ) and a matched control group (untreated cultured mammary cells). Cell viability and bleomycin dependent DNA damage were evaluated. In-vivo study shows significant increases in urinary and tissue cadmium concentrations in breast cancer patients compared to their corresponding controls $(p=0.000)$. Regarding in-vitro study, significant reduction in cell viability associated with significant increase in DNA damage were observed $(p<0.05)$. It could be concluded that the present study posits a causal association between cadmium exposure and breast cancer.
\end{abstract}

Keywords: Cadmium, Breast cancer, In-vivo, In-vitro, DNA damage.

\section{INTRODUCTION}

Cadmium is an abundant highly toxic non essential divalent heavy metal (Badisa et al., 2007). Atmospheric deposition of airborne cadmium, mining activities and application of cadmium containing fertilizers, sewage sludge on farm land with subsequent contamination of crops and vegetables grown for human consumption as well as tobacco smoking; represent important sources of cadmium exposure (Järup and Åkesson, 2009).

In Egypt, the River Nile is seriously contaminated with heavy metals including cadmium (Mansour et al., 2009). It was found that cadmium is present in significantly high concentration in atmospheric air samples (Hassanien, 2007), cucumber 
and potato samples (Mansour and Gad, 2010). Abdel-Sabour (2001) found high levels of heavy metals, including cadmium in soil, water and subsequently fish and irrigated plants in Dakahlia Governorate, Egypt. Soliman et al. (2002) considered serum cadmium levels of Dakahlia residents almost 10-fold higher than those of Cairo residents and 32 times higher than reference levels for healthy populations in the United States.

IARC (1993) had declared cadmium as a probable human carcinogen. It was linked to many environmental - induced cancers e.g. pulmonary, prostatic and testicular carcinomas (Waalkes, 2003). Worldwide, breast cancer is the most common malignancy that affects women and is considered a leading cause of death in females (Brama et al., 2007). In Egypt, it represents $37.5 \%$ of total cancer cases among Egyptian females and is considered the fourth cause of death (Elattar, 2005). Over the past decades, there has been a significant continuous increase in breast cancer rates. Yet, the underlying causes of this increase are still largely unknown (Byrne et al., 2009).

A debate has been raised regarding the role of cadmium in induction of human breast cancer (Järup et al., 1998). Since primary cell culture has the advantage of being freshly removed from the in vivo situation and therefore expected to be more closely resembling the function of the tissue (Mather and Roberts, 2002), therefore, primary cultured normal mammary cells were chosen for this study. This research aims to find out a causal association between cadmium and induction of breast cancer through in vivo study confirmed by an in vitro study to elucidate the possible toxic effects of direct exposure to cadmium on mammary cells.

\section{SUBJECTS, MATERIAL AND METHODS}

1. In vivo study: This study was conducted on 100 female patients attending Oncology Center, Mansoura University, Dakahlia Governorate, Egypt. Their ages ranged from $30-70$ years. Relevant information was obtained from each patient before surgery regarding residence, occupational history, smoking habits and reproductive history. Patients with positive family history of breast carcinoma were excluded from the study. Informed consent was obtained to get the biopsy according to the rules of the regulatory medical research ethics committee.

1.1. Study groups: Patients were divided into 2 groups. The first group (75 female patients), have histologically confirmed breast carcinoma lesions. The second group (25 female patients), have non risky non proliferative benign breast disease that served as a positive control group. 
2. Study design: $10 \mathrm{ml}$ spot urine sample and $10 \mathrm{gm}$ of breast adipose tissue were obtained from each subject. Samples were kept in polyethylene containers that were cleaned using multistep acid leaching and frozen immediately at $-20^{\circ} \mathrm{C}$ until analysis. All samples were transferred to the laboratory in an ice-box using ice chips to preserve them. Digestion was done using advanced microwave digestion system "Milestone ETHOS-1 lab station", then, cadmium concentrations were measured using ICP-spectrometer (iCAP 6000 Series; Thermo Scientific) according to manufacturer instructions.

3. In vitro study: Primary cultured normal mammary cells were prepared in the Pharmacognosy Department, Faculty of Pharmacy. It was originated from a fresh normal breast tissue that was taken distant from the lesion and confirmed histologically as normal breast tissue of a young female patient (30 years old, Mansoura resident) who was admitted to Oncology Center for excision of fibroadenoma after obtaining informed consent according to the regulatory medical research ethics guidelines.

\subsection{Cell line and culture conditions} (Mather and Roberts, 2002): Primary cultured normal mammary cells were cultured in Roswell Park Memorial Institute (RPMI) media, supplemented with
$100 \mu \mathrm{g} / \mathrm{ml}$ penicillin-streptomycin, 2.5 $\mu \mathrm{g} / \mathrm{ml}$ fungizone, $10 \%$ heat-deactivated foetal calf serum and $2 \mathrm{mM}$ glutamine. Cells were allowed to grow at $37{ }^{\circ} \mathrm{C}$ in a humidified atmosphere of $5 \% \quad \mathrm{CO}_{2}$ and 95\% air to form a monolayer, and then seeded at $1 \times 10^{4}$ cells / well in a 96-well microplate.

2.2. Chemicals: Cadmium chloride $\left(\mathrm{CdCl}_{2}\right)$, hydrochloric acid $(\mathrm{HCl} 25 \% \mathrm{v} /$ v), RPMI media, foetal calf serum, penicillin, streptomycin, fungizone, glutamine, trypan blue stain and $\mathrm{KH}_{2} \mathrm{PO}_{4}$ $\mathrm{KOH}$ buffer were purchased from Sigma - Aldrich, Co., Egypt. Ascorbic acid was purchased from Memphis Pharmaceutical Co., Egypt. Bleomycin sulfate was purchased from Cipla, India. Powdered kit for DNA analysis, Ethylenediaminetetraacetic acid (EDTA) powder and thiobarbituric acid (TBA, 1\% w/v) were purchased from Sigma, USA. Magnesium chloride $\left(\mathrm{MgCl}_{2}\right)$ and ferric chloride $\left(\mathrm{FeCl}_{2}\right)$ were purchased from El-Nasr Co., Egypt.

\subsection{Determination of $\mathrm{CdCl}_{2}$ lethal} concentration $_{50}\left(\mathrm{LC}_{50}\right)$ on primary cultured normal mammary cells: Cells were treated with $\mathrm{CdCl}_{2}$ solution at different concentrations $(0.5,5,10,20,50,100 \mu \mathrm{M})$, then incubated for $48 \mathrm{hrs}$ to determine $\mathrm{LC}_{50}$ of cadmium using trypan blue exclusion test (El-Gazzar et al., 2009). 
It was found to be $15 \mu \mathrm{M}$ (Fig. 1).

2.4. Cell treatments: Cells were divided into one test group that was treated with $\mathrm{CdCl}_{2}$ at a concentration of $15 \mu \mathrm{M}$ and a matched control group which consisted of untreated human mammary epithelial cells. All chemicals were dissolved in RPMI and then filtered with membrane filter $(0.2 \mu \mathrm{m})$ before cell treatments. Cell viability and DNA fragmentation were measured at 1, 24 and $48 \mathrm{hrs}$ to evaluate $\mathrm{CdCl}_{2}$ toxic effects by the following:

a- Evaluation of cell viability: Cells were removed from culture; then counted on haemocytometer at 1, 24 and $48 \mathrm{hrs}$. Cell viability was determined by trypan blue exclusion test. b- Bleomycin-dependent DNA damage assay: According to El-Gazzar et al. (2009), DNA damage was assayed using spectrophotometer Spekol 11. Absorbance was measured at $532 \mathrm{~nm}$.

\section{Statistical analysis}

Data were analyzed using SPSS version 16 and represented as median and interquartile range (IQR). Mann-Whitney test and Wilcoxon Signed Ranks test were performed to study the correlation between variables. Significance was set at $\mathrm{P} \leq 0.05$. Odds ratios and corresponding $95 \%$ confidence interval (CI) were calculated to estimate the magnitude of association between independent variables and elevated cadmium concentration.

\section{RESULTS}

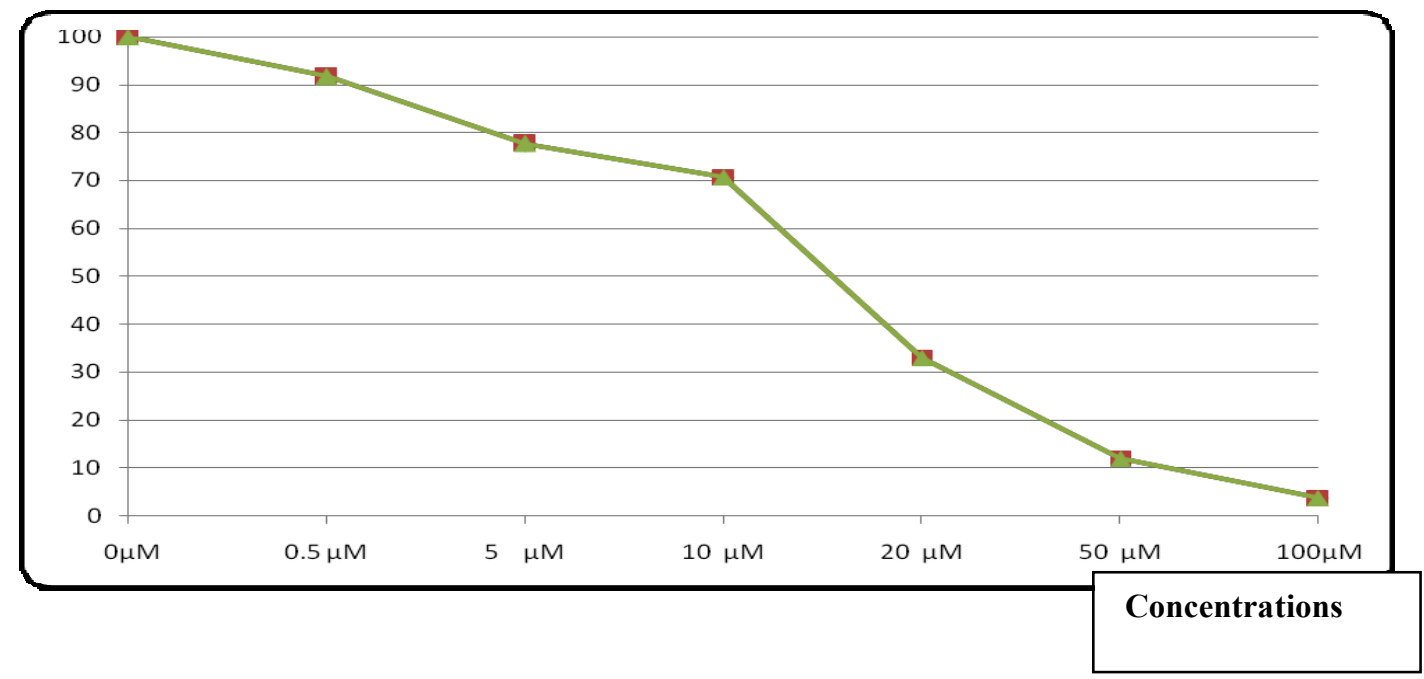

Figure (1): Determination of $\mathrm{CdCl}_{2}$ lethal concentration ${ }_{50}$ applied to primary cultured normal mammary cells. 
Table (1): Characteristics of patients of control and test groups.

\begin{tabular}{|c|c|c|c|c|c|c|}
\hline \multirow[t]{2}{*}{ Characteristics } & \multicolumn{2}{|c|}{$\begin{array}{l}\text { Positive control } \\
\text { group }(n=25)\end{array}$} & \multicolumn{2}{|c|}{$\begin{array}{c}\text { Test group } \\
(n=75)\end{array}$} & \multirow[t]{2}{*}{ Odds ratios } & \multirow{2}{*}{$\begin{array}{l}95 \% \text { Confidence } \\
\text { interval }\end{array}$} \\
\hline & $n$ & $\%$ & $n$ & $\%$ & & \\
\hline $\begin{array}{r}\text { Residence } \\
\text { Rural } \\
\text { Urban } \\
\end{array}$ & $\begin{array}{c}16 \\
9\end{array}$ & $\begin{array}{l}64 \\
16 \\
\end{array}$ & $\begin{array}{l}52 \\
23 \\
\end{array}$ & $\begin{array}{l}69.3 \\
30.7 \\
\end{array}$ & 1.272 & $0.490-3.298$ \\
\hline $\begin{array}{l}\text { Smoking } \\
\text { Smokers } \\
\\
\text { Passive smokers } \\
\text { Non smokers }\end{array}$ & $\begin{array}{c}0 \\
13 \\
12\end{array}$ & $\begin{array}{c}0 \\
52 \\
18\end{array}$ & $\begin{array}{c}0 \\
35 \\
40\end{array}$ & $\begin{array}{c}0 \\
46.74 \\
53.3\end{array}$ & 0.808 & $0.326-1.999$ \\
\hline $\begin{array}{r}\text { Marital Status } \\
\text { Married } \\
\text { Single }\end{array}$ & $\begin{array}{c}23 \\
2\end{array}$ & $\begin{array}{c}92 \\
8\end{array}$ & $\begin{array}{c}73 \\
2\end{array}$ & $\begin{array}{c}97.3 \\
2.7\end{array}$ & 3.174 & $0.423-23.812$ \\
\hline $\begin{array}{c}\text { Oral contraception } \\
\text { Positive } \\
\text { Negative } \\
\end{array}$ & $\begin{array}{l}13 \\
12 \\
\end{array}$ & $\begin{array}{l}52 \\
48 \\
\end{array}$ & $\begin{array}{l}47 \\
28 \\
\end{array}$ & $\begin{array}{l}62.7 \\
37.3 \\
\end{array}$ & 0.645 & $0.259-1.609$ \\
\hline $\begin{array}{c}\text { Menopausal status } \\
\text { Pre-menop ausal } \\
\text { Post-menop ausal }\end{array}$ & $\begin{array}{c}20 \\
5\end{array}$ & $\begin{array}{l}80 \\
20\end{array}$ & $\begin{array}{l}32 \\
43\end{array}$ & $\begin{array}{l}42.7 \\
57.3\end{array}$ & 5.375 & $1.823-15.852$ \\
\hline $\begin{array}{l}0-1 \\
2 \\
3 \text { or more }\end{array}$ & $\begin{array}{c}8 \\
6 \\
11 \\
\end{array}$ & $\begin{array}{l}32 \\
24 \\
44 \\
\end{array}$ & $\begin{array}{c}8 \\
15 \\
52 \\
\end{array}$ & $\begin{array}{c}10.7 \\
20 \\
69.3\end{array}$ & $\begin{array}{c}1 \\
2.5 \\
4.7 \\
\end{array}$ & $\begin{array}{c}0.53-12.3 \\
1.26-18.11 \\
\end{array}$ \\
\hline $\begin{array}{c}\text { Age at menopause (year) } \\
<45 \\
45-49 \\
50-54 \\
\end{array}$ & $\begin{array}{l}1 \\
4 \\
0\end{array}$ & $\begin{array}{c}4 \\
16 \\
0 \\
\end{array}$ & $\begin{array}{c}5 \\
29 \\
9\end{array}$ & $\begin{array}{c}6.7 \\
38.7 \\
12\end{array}$ & $\begin{array}{c}1 \\
1.45 \\
1.2\end{array}$ & $\begin{array}{l}0.72-1.54 \\
0.84-1.72\end{array}$ \\
\hline
\end{tabular}

Table (2): Cadmium concentrations $(\mathrm{mg} / \mathrm{kg})$ in urine and ca ncer tissue samples of positive control and test groups.

\begin{tabular}{|c|c|c|}
\hline & $\begin{array}{c}\text { Positive control group } \\
(\mathrm{mg} / \mathrm{kg})\end{array}$ & $\begin{array}{c}\text { Test group } \\
(\mathrm{mg} / \mathrm{kg})\end{array}$ \\
\hline $\begin{array}{c}\text { Urinary cadmium } \\
\text { median }\end{array}$ & $\begin{array}{c}0.0078 \\
\text { IQ R }\end{array}$ & $0.240 \uparrow^{*}$ \\
median & $(0.00165-0.0157)$ & $(0.161-0.39)$ \\
IQR Rissue cadmium & 0.0455 & $0.286 \uparrow^{*}$ \\
\multicolumn{2}{|c|}{$\uparrow$ Increased } \\
\hline \multicolumn{2}{|c|}{ * Significant at $\mathrm{P} \leq 0.05}$.
\end{tabular}

Table (3): Cell viability and Bleomycin-dependent DNA damage assay in control and test groups of primary cultured normal mammary cells.

\begin{tabular}{|c|c|c|c|c|}
\hline & \multirow{2}{*}{ Control group } & \multicolumn{3}{|c|}{$\mathbf{C d C l}_{\mathbf{2}}$ treated group } \\
\cline { 3 - 5 } & & $\mathbf{1 h r}$ & $\mathbf{2 4 h \mathbf { h }}$ & $\mathbf{4 8 h \mathbf { h }}$ \\
\hline Cell viability & 100 & $58 \downarrow^{*}$ & $61 \downarrow^{*}$ & $32 \downarrow^{*}$ \\
median & $98-100$ & $87-63$ & $58-64$ & $29-37$ \\
IQR & .082 & $.2992 \uparrow^{*}$ & $.311 \uparrow^{*}$ & $0.333 \uparrow^{*}$ \\
DNA damage & $0.081-0.083$ & $0.02-0.031$ & $0.30-0.32$ & $0.32-0.34$ \\
median & &
\end{tabular}

* Significant at $\mathrm{P} \leq 0.05$. $\quad \uparrow$ Increased $\quad \downarrow$ Decreased 


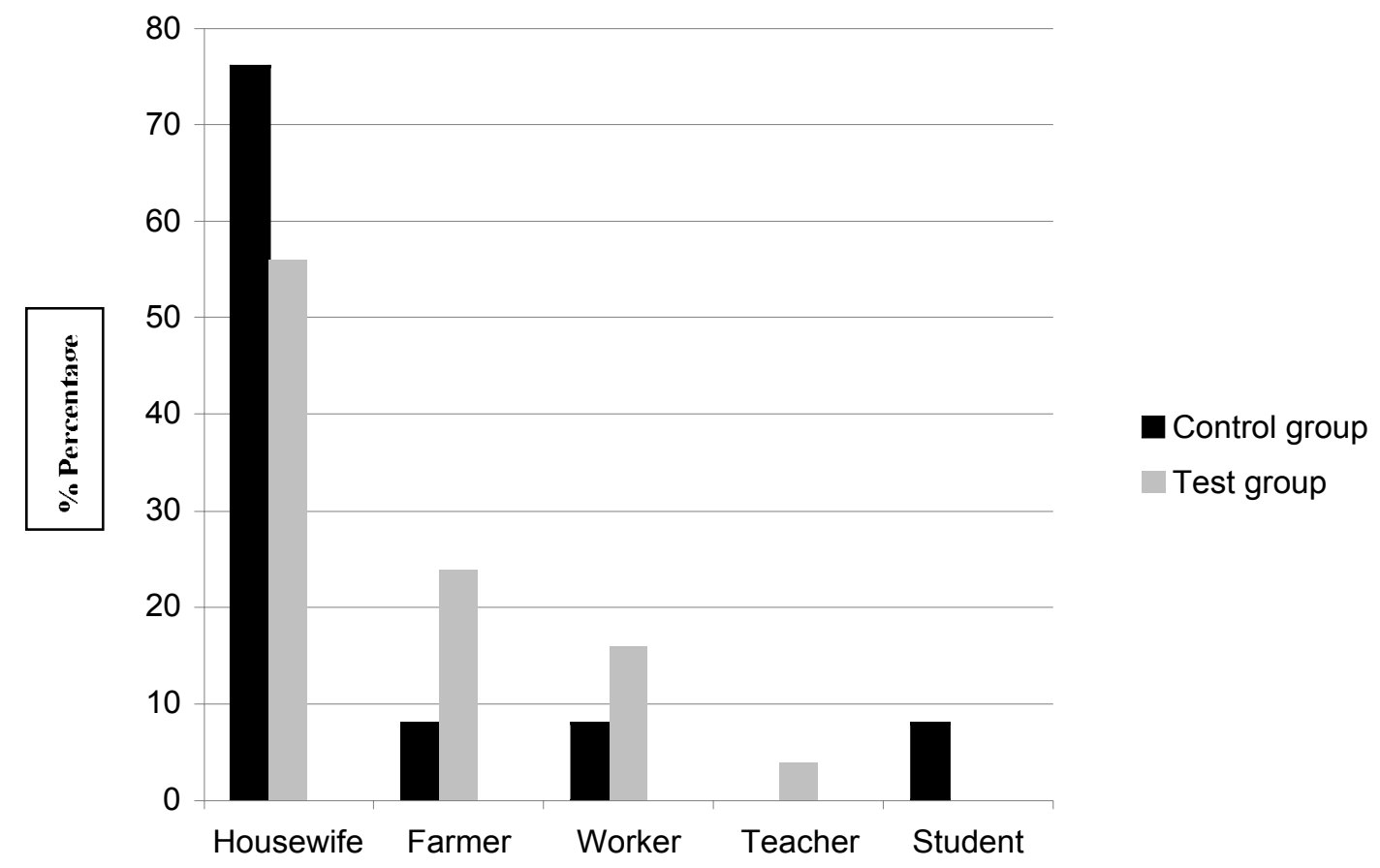

Figure (2): Percentage of occupations in test group versus control group. 
This study was conducted on 100 female patients with abnormal breast mass. The mean age for patients with benign breast disease was $40.4 \pm 11.43$, while mean age for patients with breast cancer disease was $51 \pm 9.43$.

Table (1) showed that married, rural residents and postmenopausal females had a higher risk for developing breast cancer than their corresponding controls.

In patients with breast cancer, median values of cadmium concentration were $0.240 \mathrm{mg} / \mathrm{kg}(0.161-0.39)$ in urine samples and $0.286 \mathrm{mg} / \mathrm{kg}(0.168-0.598)$ in cancer tissue samples, while in patients with benign tumor, the corresponding values were $0.008 \mathrm{mg} / \mathrm{kg}(0.002-0.016)$ and 0.046 $\mathrm{mg} / \mathrm{kg}(0.016-0.083)$ respectively. A statistically significant difference in cadmium concentrations were observed in urine and tissue samples of patients with malignant lesions compared to corresponding groups of patients with benign lesions $(\mathrm{P}=.000$ for each) (Table 2$)$.

Table (3) demonstrated significant reduction in cell viability with significant increase in DNA damage in cadmium treated group compared to control group ( $\mathrm{p} \leq$ 0.05 for each).

\section{DISCUSSION}

Cadmium is a ubiquitous environmen- tal pollutant which has several known adverse health effects including carcinogenesis (Ferrigno et al., 2009). Breast carcinoma is considered the most common malignancy that can affect women and cause death worldwide (Brama et al., 2007). This study was designed to elucidate the causal relation between cadmium and induction of breast cancer.

Data of the present work revealed that female patients who lived in rural areas represented higher risk incidence for developing breast cancer than those lived in urban areas which differs from Lannin et al. (1998), they stated that breast cancer is recognized as a disease that occurs more often among women of the upper social classes. No significant risk difference was detected regarding smoking habits in patients with breast cancer and those with benign breast diseases. Housewives and farmers represented the highest incidence in developing breast cancer (figure 2).

In the present study, married women were at higher risk for developing breast cancer. This was in disagreement with Kuehn et al. (2000), who reported that never-married women over age 40 have been found to have a higher risk of breast cancer than those who have been married, an association attributed to a reduced risk associated with childbearing.

Postmenopausal females were at higher 
risk to have breast cancer especially after 45 years old. This finding supports previous work done by Antila et al. (1996) who reported that post-menopausal breast cancer patients having a decline in their progesterone levels and increasing cadmium concentrations by age can have increased risk of breast cancer. McElory et al. (2006) showed that premenopausal younger women were at higher risk for breast cancer with increased cadmium concentration.

From such results, it was suggested that diet and water may be the main sources for cadmium exposure as most of the study group were non occupationally exposed housewives and farmers who lived in rural areas as well as non of patients were active smokers; that indicates low socioeconomically status subsequently they may have been depended mainly on cereals and vegetables in their diet. This suggestion goes in consistence with McElory et al. (2006), who stated that for nonoccupationally exposed women who do not smoke, food is the largest source for cadmium intake.

Supporting these results, Kriegel et al. (2006) reported that River Nile and subsequently irrigated plants were seriously contaminated with heavy metals including cadmium. Other studies were done by Mansour et al. (2009); Mansour and Gad, (2010) who studied risk assessment of pesticides and heavy metals contaminants in vegetables and fruits as cucumber and potato samples.

In the current study, urinary cadmium concentration that indicates long life exposure; in patients with breast cancer was significantly higher than that of patients with benign breast diseases. These results go in consistence with McElory et al. (2006), who carried out a population, based case central study on 246 women with breast cancer. They estimated cadmium concentration in urine samples in which they found a statistically significant two folds increase in breast cancer risk for women having higher cadmium concentrations.

Another study was done by Strumylaite et al. (2010), who estimated urinary cadmium concentration in 57 breast cancer patients versus 51 patients with benign breast diseases. They demonstrated significantly higher cadmium concentration in patients with breast cancer compared to patients with benign breast diseases.

Data of this study reveals that tissue cadmium concentration that represents accumulation of cadmium in breast in patients with breast cancer was significantly higher than that of patients with benign breast diseases. This was in disagreement with a study that was done by Antila et al. (1996), they analyzed cadmium concentration in 43 breast cancer patients versus 32 
healthy controlled subjects and concluded that mean cadmium concentration in cancer patients did not differ significantly from healthy control; although it was found in high concentrations in both groups. They accounted the cadmium is tightly bound and poorly excreted in human breast milk.

Other subsequent studies were in consistence to results of this study, Ionescu et al. (2006) performed analysis for heavy metals concentrations in relation to breast cancer in a study of 20 frozen breast cancer biopsies. They found that cadmium was significantly higher in cancer biopsies than healthy control group.

Another study was done by Strumylaite et al. (2008), who assessed cadmium concentration in breast tissue samples in patients with breast cancer $(n=21)$ versus those with benign breast diseases $(n=19)$. They revealed a statistically significant difference in cadmium concentrations between malignant and benign breast tissues.

As well as, Strumylaite et al. (2010) underwent a study on 57 breast cancer patients and 51 benign diseases. They estimated cadmium concentrations in biological media including diseased biopsy, healthy tissue, urine and blood for each patient, where they stated that cadmium content in malignant tumors were significantly higher than that of benign tissue with no significant difference in healthy tissue between both. They explained the result of Antila et al. (1996) is that cadmium analysis may be done in the tissue near to the malignant tissue but not in the malignant tissue.

To our knowledge, this is the first study of the genotoxic effects of cadmium using primary cultured normal mammary cells. Results of this research indicate that cadmium is significantly cytotoxic to primary cultured mammary cells in a time dependent manner; cell viability was reduced to about $33 \%$.

These results go in consistence with several studies that were done on mammary epithelial cell lines; Roy et al. (2004) studied the toxic effect of cadmium in normal (MCF-12A and MCF-12F) and cancerous (MCF-7, BT-549 and 11-9-1-4) human mammary epithelial cell lines. They found that cadmium modified the morphological characters on all cell lines at doses higher than $10 \mu \mathrm{M}$. Meanwhile, Klutse et al. (2009) studied the toxicological interactions among metals on MCF-7 cell line. Cells were exposed to individual and composite mixture of the toxic metals according to their MCLs (maximum contamination levels) for 24 hours, cadmium was the second most toxic metal to the mammary cells and toxicity was enhanced three times higher in the composite mixture; 
they accounted such effect to compromising the cell detoxification process.

Similar effects of cadmium on mammary cells were detected in other different cell cultures as reported by Ishido and $\mathrm{Ku}$ nimoto, 2001 who stated that induced cytotoxic effects in different cell lines such as porcaine renal culture, rat proximal tubular cells, human $\mathrm{T}$ cell hybridoma, rat liver and immunocytes, as well as, Henson and Chedrese et al. (2004) they reported that cadmium induced cytotoxicity and cell death in ovarian cells at high concentration.

Cytotoxic effects of cadmium could be explained by the profound destabilizing effect of cadmium on lysosomes with different degrees from cell to call according to the metabolic activity; a feature that was stated by Marigomez et al. (1989) who studied the effect of sublethal concentrations of cadmium on digestive gland lysosomal system of marine prosobranch littorina littorea. Another hypothesis was stated by Henson and Chedrese et al. (2004) who referred to cytotoxicity to its apoptogenic nature and the ability of cadmium to disrupt cell membranes and increase $\mathrm{Ca}^{+2}$ ion influx which may account for these toxic effects.

These results were supported by the studies of Dally and Hartwig, (1997); they reported in their study on human Hela cells; that cadmium is known to be taken efficiently by mammalian cells in culture with the ability to accumulate intracellularly 10 folds more than extracelluarly. Cadmium entry to mammalian cells is frequently through L-type voltage $\mathrm{Ca}^{+2}$ channels and receptor mediated $\mathrm{Ca}^{+2}$ channels Henson and Chedrese et al. (2004).

In the present research, a significant DNA damage was observed, a finding that goes in agreement with Roy et al. (2004), who stated that cadmium can induce DNA damage in different mammary cell lines. They attributed these effects to induction of oxidative DNA damage or their interaction with DNA repair mechanisms.

This damage may be due to the ability of cadmium to increase reactive oxygen species resulting in lipid peroxidation, DNA damage and altered gene expression as suggested by Badisa et al. (2007); or due to inactivation of the enzymes responsible for DNA repair by displacing essential metal ions especially zinc ions at zinc finger structure (Hanas and Gunn, 1996).

In conclusion, data of this study show significant elevation of urinary and tissue cadmium concentrations in breast cancer patients associated with significant reduction in cell viability and significant increase in LDH concentration and DNA 
damage in primary cultured normal association between cadmium exposure mammary cells; which can posit a causal and breast cancer. 


\section{REFERENCES}

Abdel-Sabour, M. F. (2001) : "Cadmium status in Egypt". J. Environ. Sci., 13: 351-360.

Antila, E.; Mussalo-Rauhamaa, H.; Kantola, M.; Atroshi, F. and Westermarck, T. (1996): "Association of cadmium with human breast cancer." The Science of the Total Environment, 186: 251-256.

Badisa, V. L. D.; Latinwo, L. M.; Odewumi, C. O.; Ikediobi, C. O.; Badisa, R. B. and Ayuk-Takem, L. T. (2007) : "Mechanism of DNA damage by cadmium and interplay of antioxidant enzymes and agents." Environ. Toxicol., 22(2): 144-151.

Brama, M.; Gnessi, L.; Basciani, S.; Cerulli, N.; Politi, L. and Spera, G. (2007): "Cadmium induces mitogenic signaling in breast cancer cell by an ER-dependent mechanism." Molecular and Cellular Endocrinology, 264: 102-108.

Byrne, C.; Divekar, S. D.; Storchan, G. B.; Parodi, D. A. and Martin, M. B. (2009): "Cadmium - a metallohormone?" Toxicol. Appl. Pharmacol., 238(3): 266-271.

Dally, H. and Hartwig, A. (1997) : "Induction and repair inhibition of oxidative DNA damage by nickel (II) and cadmium (II) in mammalian cells." Carcinogenesis, 18 (5): 1021-1026.
Elattar, I. (2005) : Cancer registration, National Cancer Institute, Egypt.

El-Gazzar, A. B. A.; Youssef, M. M.; Youssef, A. M. S.; Abu-Hashem, A. A. and Badria, F. A. (2009) : "Design and synthesis of azolopyrimidoquinolines, pyrimidoquinazolines as anti-oxidant, antiinflammatory and analgesic activities." European Journal of Medicinal Chemistry, 44(2): 609-624 .

Ferrigno, A.; Gregotti, C.; Richelmi, P. and Vairetti, M. (2009) : "Dexamethasone protects cultured rat hepatocytes against cadmium toxicity: involvement of cellular thiols." In Vitro Cell. Dev. Biol. Animal, 46(5):445 - 449.

Hanas, J. S. and Gunn, C. G. (1996) : "Inhibition of transcription factor IIIADNA interactions by xenobiotic metal ions." Nucleic Acids Res., 24: 924-930.

Hassanien, M. A. (2007) : "Risk assessment of atmospheric toxic pollutants over Cairo, Egypt." Cairo Univers. J. Environ. Sci., 5(1): 37-57.

Henson, M. C. and Chedrese, P. J. (2004) : "Endocrine disruption by cadmium, a common environmental toxicant with paradoxical effects on reproduction." Exp. Biol. Med., 229(5): 383-392.

IARC (International Agency for Re- 
search on Cancer) (1993) : "Cadmium and cadmium compounds. In: Beryllium, cadmium, mercury, and exposures in the glass manufacturing industry." Working Group views and expert opinions, Lyon, France, Monogr Eval Carcinog. Risks Hum., 58: 41-117.

Ionescu, J. G.; Novotny, J.; Stejskal, V.; LÄtsch, A.; Blaurock-Busch, E. and Eisenmann-Klein, M. (2006) : "Increased levels of transition metals in breast cancer tissue." Neuro. Endocrinol. Lett., 27(1): 36-39.

Ishido, M. and Kunimoto, M. (2001) : "Regulation of cell fate by cadmium and zinc." J. Health Sci., 47(1): 9 - 13.

Järup, L. and Åkesson, A. (2009) : "Current status of cadmium as an environmental health problem." Toxicol. Appl. Pharmacol., 238: 201-208.

Järup, L.; Berglund, M.; Elinder, C. G.; Nordberg, G. and Vahter, M. (1998) : "Health effects of cadmium exposure -a review of the litreture and a risk estimate." Scand. J. Work Environ. Health, 24(1): 1 52.

Klutse, C. K.; Mack, K.; Squibb, K. and Ishaque, A. B. (2009) : "Differential toxicological interaction among arsenic, cadmium, lead, and mercury on MCF7 cell line." Scholarly Research Exchange, $1: 5$.
Kriegel, A. M.; Soliman, A. S.; Zhang, Q.; El-Ghawalby, N.; Ezzat, F.; Soultan, A.; Abdel-Wahab, M.; Fathy, O.; Ebidi, G.; Bassiouni, N.; Hamilton, S. R.; Abbruzzese, J. L.; Lacey, M. R. and Blake, D. A. (2006) : "Serum cadmium levels in pancreatic cancer patients from the east Nile Delta region of Egypt." Environ. Health Perspect., 114(1): 113-119.

Kuehn, T.; Klauss, W.; Darsow, M.; Regele, S.; Flock, F.; Maiterth, C.; Dahlbender, R.; Wendt, I. and Kreienberg, R. (2000) : "Long-term morbidity following axillary dissection in breast cancer patients-clinical assessment, significance for life quality and the impact of demographic, oncologic and therapeutic factors." Breast Cancer Res. Treat., 64(3): 275-286.

Lannin, D. R.; Mathews, H. F.; Mitchell, J.; Swanson, M. S.; Swanson, F. H. and Edwards, M. S. (1998) : "Influence of socioeconomic and cultural factors on racial differences in late-stage presentation of breast cancer." J.A.M.A., 279 (22): 18011807.

Mansour, S. A. and Gad, M. F. (2010): "Risk assessment of pesticides and heavy metals contaminants in vegetables: A novel bioassay method using Daphnia magna Straus." Food and Chemi. Toxicol., 48 (1): 377- 389.

Mansour, S. A.; Belal, M. H.; Abou- 
Arab, A. A. K. and Gad, M. F. (2009) : "Monitoring of pesticides and heavy metals in cucumber fruits produced from different farming systems."Chemosphere, 75 (5): 601-609.

Marigomez, J. A.; Vega, M. M.; Cajaraville, M. P. and Angulo, E. (1989) : "Quantitative responses of the digestivelysosomal system of winkles to sublethal concentrations of cadmium." Cell Mol. Biol., 35: 555-562.

Mather, J. P. and Roberts, P. E. (2002): Primary Cultures. In: Introduction to Cell and Tissue Culture Theory and Technique. Library of Congress Cataloging-inPublication Data, Genentech Inc., South San Francisco, California, P. P. 151-165.

McElroy, J. A.; Shafer, M. M.; Trentham-Dietz, A.; Hampton, J. M. and Newcomb, P. A. (2006) : "Cadmium exposure and breast cancer risk". Journal of the National Cancer Institute, 98(12): 869-873.

Roy, S. S.; Mukherjee, S.; Mukhopadhyay, S. and Das, S. K. (2004) : "Differential effect of cadmium on cholinephospho- transferase activity in normal and cancerous human mammary epithelial cell lines." Mol. Cancer Ther., 3: 199-204.

Soliman, A. S.; El-Ghawalby, N.; Ezzat, F.; Bondy, M. L.; Soultan, A.; AbdelWahab, M. (2002) : "Unusually high rate of young-onset pancreatic cancer in the East Nile Delta region of Egypt." Int. J. Gastrointes. Can., 32: 143-151.

Strumylaite, L.; Bogusevicius, A.; Ryselis, S.; Pranys, D.; Poskiene, L.; Kregzdyte, R.; Abdrachmanovas, O. and Asadauskaite, R. (2008) : "Association between cadmium and breast cancer." Medicina (Kaunas), 44(6): 415-420.

Strumylaite, L.; Bogusevicius, A.; Abdrachmanovas, O.; Baranauskiene, D.; Kregzdyte, R.; Pranys, D. and Poskiene, L. (2010) : "Cadmium concentration in biological media of breast cancer patients." Breast Cancer Res. Treat., DOI 10.1007/ s10549-010-1007-8.

Waalkes, M. P. (2003) : "Cadmium carcinogenesis". Mutat. Res., 533(1-2): 107127. 


\section{دراسة داخلية فى الجسم الحى و دراسة منتبرية خارجة الجسم للعلاقة بين عنصر الكاد ميو م وسرطان الثدى لئر}

$$
\text { المشتركون فى البحث }
$$

أ. כ. عادل هــهـود الهنصــورى

$$
\begin{aligned}
& \text { أ. د. عنسى أحهـد الحـارونـى } \\
& \text { أ . د. فربيد عبدالرحيم بدربه* }
\end{aligned}
$$

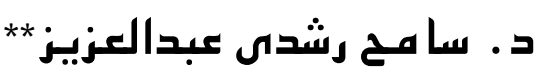$$
\text { أ. م. د. أهال عبدالسلام البقرى }
$$$$
\text { ط. هـنـــ محـهــود أبوالعطلـا }
$$

من أقسام الطب الشرعى والسموم الإكلينيكية - كلية الطب، العقاقير - كلية الصيدلة*

$$
\text { مركـز الأورام **، جامعـة المنصسورة }
$$

يعتبر عنصر الكادميوم ملوث سرطانى بيئى فعال وقد تم ربطه فى الآونة الأخيرة بسرطان الثدى، وقد أجرى هذا البحث من خلال دراسة داخلية فى الجسم الحى ودراسة مختبرية خارج الجسم لاكتشاف العلاقة بين الكادميوم وسرطان الثدى.

- الدراسة الداخلية فى الجسم الحى تم إجرائها على . . 1 سيدة تم إختيارهم عشوائياً من المترددات على مركز الأورام - جامعة المنصورة،

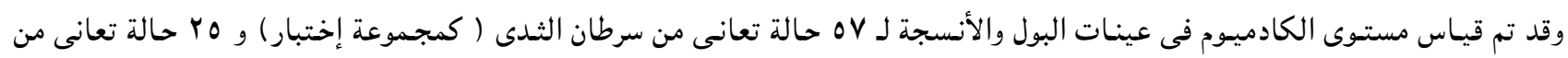
أورام حميدة (كمجموعة ضابطة) باستخدام مطياف البلازما المزدوجة.

- الدراسة المختبريـة الخارجية تمت على خلايا طبيعية أولية ومستنبتة من نسيج الثدى، وقد تم تقسيم الخلايا إلى مجموعتين : مجموعة تجريبية تم معالجتها بالكادميوم (تركيز 10 ميكرومول) ومجموعة ضابطة، وتم قياس حيوية الخلايا ودرجة تكسير الحامض النووى باستخدام مادة البليوميسين. وقد أظهرت نتائج الدراسة الداخلية إرتفاع نسبة الكادميوم فى البول والأنسجة السرطانية إرتفاع ذو دلالة إحصائية عالية الأهمية مقارنة بالمجموعة الضابطة، كما أظهرت الدراسة الخارجية إنخفاضا" فى حيوية الخلايا وارتفاع فى نسبة تكسير الحامض النووى وكلاهما ذو دلالة إحصائية، ويككن أن نستخلص من هذه الدراسة أن هناك علاقة سببية بين التعرض للكادميوم وسرطان الثدى. 